\title{
KEANEKARAGAMAN DAN KELIMPAHAN FILUM ECHINODERMATA PADA ZONA INTERTIDAL MOLAS KECAMATAN BUNAKEN KOTA MANADO
}

\author{
(Diversity and Abundance of Phylum Echinoderms on Intertidal Zone of Molas, Sub-district of \\ Bunaken, Manado City)
}

\author{
Novia A. Jambo ${ }^{1}$, Erly Y. Kaligis ${ }^{1 *}$, Deslie R.H. Kumampung ${ }^{1}$, Suria Darwisito ${ }^{1}$, Joshian \\ N.W. Schaduw ${ }^{1}$, Silvester B. Pratasik ${ }^{2}$
}

1Program Studi IImu Kelautan, FPIK, UNSRAT

2Program Studi Budidaya Perairan, FPIK, UNSRAT

*E-mail: erly_kaligis@yahoo.co.id

\begin{abstract}
Echinoderms are one of the main components of marine biodiversity that play an important role in ecosystem function. The purpose of this study to determine the diversity, abudance,dominance, frequency and important value index of the phylum Echinoderm. The method use in this research was cruising method and the quadratic transect method. The results of this study on intertidal zone of Molas obtained as a whole includes four classes, namely Asteroidea, Echinoidea, Ophiuroidea and Holothuroidea with a total of 12 species. Based on data analysis used the quadratic transect method, it was obtained: at station I $\mathrm{H}^{\prime}$ $=1.666$, the highest species abundance index is Protoreaster nodosus at $1.133 \mathrm{ind} / \mathrm{m} 2$ and relative at $40.48 \%, C=0.245$ and the highest relative dominance of $P$. nodusus was $66.90 \%$, the highest species frequency index is $P$. nodusus of 0.467 and a relative of $33.33 \%$ and the highest important value index is $P$. nodusus of $140.71 \%$ while at station II it is obtained $\mathrm{H}^{\prime}=$ 1,384 , The highest species abundance index is Diadema setosum at $3.067 \mathrm{ind} / \mathrm{m} 2$ and relative $55.42 \%, C=0.359$ and the highest relative dominance is $D$. setosum at $85.63 \%$, the highest species frequency index is $P$. nodusus at 0.4 and relative at $27.27 \%$ and the highest important value index of $D$. setosum was $159.23 \%$.
\end{abstract}

\begin{abstract}
Keywords: Echinoderms, Diversity, Abundance, Dominance, Frequency, Important Value Index

Echinodermata merupakan salah satu komponen utama dari keanekaragaman hayati di laut yang memainkan peran penting dalam fungsi ekosistem. Tujuan dari penelitian ini yaitu mengetahui keanekaragaman, kelimpahan, dominansi, frekuensi dan indeks nilai penting Filum Echinodermata. Metode yang digunakan adalah metode jelajah (cruise method) dan metode transek kuadrat. Hasil penelitian pada zona intertidal Molas yang diperoleh secara keselurahan meliputi empat kelas yaitu Asteroidea, Echinoidea, Ophiuroidea, dan Holothuroidea dengan total 12 jenis. Berdasarkan analisis data menggunakan metode transek kuadrat, maka diperoleh: pada stasiun I $H^{\prime}=1,666$, indeks kelimpahan jenis tertinggi yaitu Protoreaster nodusus sebesar $1,133 \mathrm{ind} / \mathrm{m}^{2}$ dan relatif sebesar $40,48 \%, C=0,245$ dan dominansi relatif tertinggi $P$. nodusus sebesar $66,90 \%$, indeks frekuensi jenis tertinggi $P$. nodusus sebesar 0,467 dan relatif sebesar $33,33 \%$ dan INP tertinggi $P$. nodusus sebesar $140,71 \%$ sedangkan pada stasiun II diperoleh $H^{\prime}=1,384$, indeks kelimpahan jenis tertinggi Diadema setosum sebesar $3,067 \mathrm{ind} / \mathrm{m}^{2}$ dan relatif $55,42 \%, C=0,359$ dan dominansi relatif tertinggi $D$. setosum sebesar $85,63 \%$, indeks frekuensi jenis tertinggi $P$. nodusus sebesar 0,4 dan relatif sebesar $27,27 \%$ dan INP tertinggi $D$. setosum sebesar $159,23 \%$.
\end{abstract}

Kata kunci: Echinodermata, Keanekaragaman, Kelimpahan, Dominansi, Frekuensi, Indeks Nilai Penting 


\section{PENDAHULUAN}

Laut Indonesia memiliki keanekaragaman hayati yang cukup tinggi, salah satunya adalah filum Echinodermata. Menurut Supono dkk. (2014), Echinodermata merupakan salah satu komponen utama dari keanekaragaman hayati di laut yang memainkan peran penting dalam fungsi ekosistem. Biota laut ini dapat bersifat pemakan seston atau pemakan detritus, sehingga peranannya dalam suatu ekosistem untuk merombak sisa-sisa bahan organik yang tidak terpakai oleh spesies lain namun dapat dimanfaatkan oleh Echinodermata (Dahuri, 2003).

Echinodermata

merupakan

hewan invertebrata yang secara morfologis memiliki bentuk tubuh simetri radial. Echinodermata dibagi menjadi 5 kelas yaitu Asteroidea, Echinoidea, Ophiuroidea, Crinoidea dan Holothuroidea. Di Indonesia dan sekitarnya terdapat 5 kelas filum Echinodermata yang terdiri dari 141 jenis teripang, 87 jenis bintang laut, 142 jenis bintang ular laut, 84 jenis bulu babi dan 91 jenis lili laut (Fitriansyah $d k k$., 2018).

Keanekaragaman dan kelimpahan Echinodermata sangat dipengaruhi oleh faktor fisik dan kimia pada masing - masing daerah. Beberapa peneliti mengemukakan bahwa keanekaragaman tertinggi Echinodermata terdapat pada daerah terumbu karang, tetapi keberadaannya juga dapat ditemukan pada mangrove dan lamun (Katili, 2011; Rompis dkk., 2013; Zamani, 2015). Pada umumnya setiap jenis memiliki habitat yang spesifik, seperti misalnya Holothuria scabra yang sering dijumpai di daerah berpasir atau pasir berlumpur yang banyak ditumbuhi lamun (Ariyanto, 2016).

Perairan Molas berlokasi di Kecamatan Bunaken, Kota Manado, Sulawesi Utara. Perairan ini merupakan tempat wisata yang belum terekspos karena pengunjungnya hanya beberapa dari luar daerah dan masyarakat setempat saja. Penelitian tentang keanekaragaman filum Echinodermata di Perairan Sulawesi Utara telah dilakukan, diantaranya seperti Budiman dkk. (2014) di pantai Basaan Satu
Kecamatan Ratatotok, Tahe (2013) di pantai Tanamon Kecamatan Sinonsayang, Yusron (2010) di perairan Likupang, Minahasa Utara. Namun, kajian tentang Echinodermata di perairan Molas belum banyak dilaporkan.

Tujuan dari penelitian ini adalah menganalisis keanekaragaman, kelimpahan, dominansi, frekuensi dan nilai penting filum Echinodermata pada zona intertidal Molas, Kecamatan Bunaken, Kota Manado.

\section{METODE PENELITIAN}

\section{Waktu dan Lokasi Penelitian}

Penelitian ini dilaksanakan selama \pm 6 bulan yaitu pada bulan Februari sampai Juli 2021. Lokasi penelitian bertempat di perairan Molas, Kecamatan Bunaken, Kota Manado (Gambar 1).

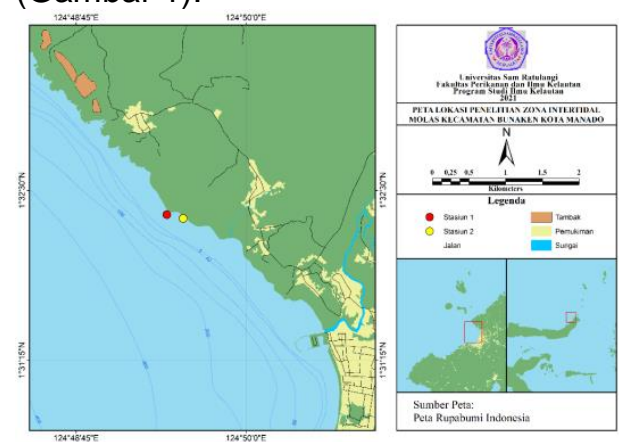

Gambar 1. Peta Lokasi Penelitian

\section{Prosedur Penelitian}

Pengambilan data dilakukan dengan menggunakan metode jelajah (cruise method) dan metode transek kuadrat secara purposive sampling. Metode jelajah bertujuan untuk mengetahui komposisi jenis Echinodermata pada zona intertidal Molas. Kemudian dilanjutkan dengan metode transek kuadrat yang digunakan untuk mengetahui indeks ekologi Echinodemata pada zona intertidal Molas.

Metode pertama dalam penelitian ini dilakukan dengan menelusuri roll meteran yang ditarik secara acak dari pantai menuju laut pada lokasi yang sudah ditentukan. Pengambilan data dengan menggunakan metode jelajah dilakukan pada 2 stasiun dan diberi jarak $500 \mathrm{~m}$ antara stasiun pengambilan pertama ke stasiun selanjutnya. Area 
jelajah yang akan diamati sepanjang $300 \mathrm{~m}$ pada setiap stasiun. Kemudian dilakukan pengamatan dengan mencatat jumlah jenis dan jumlah individu dari masing-masing jenis biota yang didapat menggunakan alat tulis menulis. Jenis biota yang didapat diambil menggunakan sarung tangan atau penjepit kemudian diletakkan pada papan alas untuk di dokumentasi menggunakan kamera serta dilakukan identifikasi menggunakan buku identifikasi.

Selanjutnya untuk metode kedua yaitu garis transek ditarik tegak lurus dari pantai menuju laut kemudian diletakkan plot kuadrat secara zig-zag disamping garis transek. Plot yang diamati sebanyak 5 buah dan diberi jarak masing-masing 2 meter. Metode transek kuadrat dilakukan pada 2 stasiun yang telah ditentukan dengan jarak $300 \mathrm{~m}$ antara stasiun pertama ke stasiun selanjutnya. Pengambilan data dilakukan sebanyak 3 kali ulangan pada setiap stasiun dan diberi jarak $50 \mathrm{~m}$ dari garis transek pertama menuju garis transek lainnya. Biota Echinodermata yang terdapat dalam kuadrat dicatat jumlah jenis, jumlah individu, dan tipe substrat yang di tempati.

\section{Pengukuran Parameter Fisika-Kimia Perairan}

Pengukuran parameter

lingkungan pada lokasi penelitian meliputi:

1. Parameter fisik yaitu pengukuran suhu perairan menggunakan termometer.

2. Parameter kimia yaitu pengukuran derajat keasaman $(\mathrm{pH})$ dan salinitas perairan menggunakan kertas lakmus dan refraktometer.

\section{Identifikasi Jenis}

Setelah melakukan pengambilan dan pengumpulan data, selanjutnya dilakukan identifikasi jenis biota Echinodermata. Pada proses ini jenis biota Echinodermata diambil menggunakan penjepit kemudian diletakkan diatas papan alas. Biota yang telah diketahui jenisnya langsung diidentifikasi di lapangan. Identifikasi mencakup morfologi seperti bentuk tubuh, warna tubuh, serta ukuran tubuh dari biota Echinodermata. Untuk identifikasi jenis Echinodermata dilakukan dengan mengacu pada Clark dan Rowe (1971), Rowe dan Doty (1977) Colin dan Arneson (1995) dan WoRMS (2021). Dari proses identifikasi, biota yang telah diketahui jenis dan jumlahnya kemudian akan dianalisis tingkat keanekaragaman, kelimpahan, frekuensi serta nilai penting dari biota.

\section{Analisis Data \\ Indeks Keanekaragman Jenis} Indeks

keanekaragaman

digunakan untuk mengetahui tingkat keanekaragaman Echinodermata di zona intertidal Molas dengan menggunakan rumus Shannon-Wiener:

Keterangan:

$$
\mathrm{H}^{\prime}=-\sum \frac{\mathrm{ni}}{\mathrm{N}} \ln \frac{\mathrm{ni}}{\mathrm{N}}
$$

$\mathrm{H}^{\prime}$ = indeks keanekaragaman jenis

ni = jumlah individu dari suatu jenis $\mathrm{i}$

$\mathrm{N}=$ jumlah total individu seluruh jenis

\section{Indeks Kelimpahan Jenis}

Kelimpahan masing-masing jenis pada setiap lokasi pengamatan dihitung dengan menggunakan rumus (Odum, 1994) sebagai berikut:

$$
\mathrm{Di}=\frac{\mathrm{ni}}{\mathrm{A}}
$$

Keterangan:

Di $=$ Kelimpahan Jenis (ind $/ \mathrm{m}^{2}$ )

$\mathrm{ni}=$ Jumlah total individu suatu jenis

$A=$ Luas daerah yang disampling $\left(\mathrm{m}^{2}\right)$

\section{Indeks Kelimpahan Relatif}

Kelimpahan relatif merupakan presentase dari jumlah individu terhadap jumlah total individu yang terdapat di daerah tertentu, di hitung menggunakan rumus (Odum, 1994):

Keterangan:

$$
\mathrm{RDi}=\left[\frac{\mathrm{ni}}{\sum \mathrm{n}}\right] \times 100 \%
$$

$\mathrm{RDi}=$ Kelimpahan relatif

ni = Jumlah total jenis $\mathrm{i}$ (individu)

$\sum \mathrm{n}=$ Jumlah total individu seluruh jenis 
Indeks Dominansi Jenis

Indeks dalam karakter komunitas antar stasiun, yaitu nilai Dominansi spesies, dalam penganalisisan (Odum, 1994):

$$
\mathrm{C}=\sum(\mathrm{ni} / \mathrm{N})^{2}
$$

Keterangan:

$\mathrm{C}=$ Dominasi jenis

$n i=$ Jumlah individu jenis $\mathrm{i}$

$N=$ Jumlah total individu seluruh jenis

\section{Indeks Dominansi Relatif}

Dominansi relatif dianalisis menurut perumusan dari Odum (1994), yaitu:

$$
\text { RCI }(\%)=\frac{\text { Dominansi jenis A }}{\text { Dominansi total jenis }} \times 100
$$

\section{Indeks Frekuensi Jenis}

Frekuensi jenis adalah peluang suatu jenis ditemukan dalam titik lokasi yang akan diamati. Frekuensi jenis dihitung dengan rumus (Odum, 1994):

$$
\mathrm{Fi}=\frac{\mathrm{Pi}}{\sum \mathrm{p}}
$$

Keterangan :

$\mathrm{Fi}=$ Frekuensi jenis $\left(\mathrm{ind} / \mathrm{m}^{2}\right)$

$\mathrm{Pi}=$ Jumlah petak dimana ditemukannya suatu jenis $\Sigma p=$ Jumlah seluruh plot pengamatan

\section{Indeks Frekuensi Relatif}

Indeks frekuensi relatif adalah perbandingan antara frekuensi jenis (Fi) dengan jumlah frekuensi semua jenis ( $\mathrm{Fi})$ (Odum, 1994):

$$
\mathrm{RFi}=\left[\frac{\mathrm{Fi}}{\sum \mathrm{fi}}\right] \times 100 \%
$$

Keterangan:

$\mathrm{Rfi}=$ Frekuensi jenis relatif

$\mathrm{Fi}=$ Frekuensi jenis $\mathrm{i}$

$\Sigma \mathrm{fi}=$ Frekuensi seluruh jenis

\section{Indeks Nilai Penting}

Nilai penting merupakan hasil penjumlahan dari kelimpahan relatif, dominansi relatif dan frekuensi relatif. Indeks nilai penting memiliki kisaran antara 0-300. Dalam perhitungan indeks nilai penting menggunakan rumus (Brower, dkk. 1989):

$$
\mathrm{INP}=\mathrm{RDi}+\mathrm{RFi}+\mathrm{RCi}
$$

Keterangan:

INP = Nilai Penting

$\mathrm{RDi}=$ Kepadatan relatif

$\mathrm{RFi}=$ Frekuensi relatif

$\mathrm{RCi}=$ Dominansi Relatif

\section{Tipe substrat}

Substrat pada suatu perairan menentukan adanya kelangsungan hidup organisme yang mendiami perairan tersebut. Perbedaan tipe substrat dapat pula membedakan jenis Echinodermata pada lokasi penelitian. Pada zona intertidal lokasi penelitian memiliki beberapa tipe substrat dasar berupa pasir, lumpur, berbatu, maupun pecahan karang. Untuk itu perlu adanya pengamatan tipe substrat pada lokasi pengambilan data.

\section{HASIL DAN PEMBAHASAN}

Penelitian dilakukan pada zona intertidal Molas yang bertempat di Kelurahan Molas, Kecamatan Bunaken, Kota Manado. Perairan pantai Molas memiliki luasan kurang lebih 7,98 $\mathrm{Ha}$ (Sara $d k k$., 2020). Jarak yang ditempuh menggunakan jalur darat dari pusat Kota Manado menuju lokasi penelitian kurang lebih $10 \mathrm{~km}$. Akses menuju perairan Molas juga dapat ditempuh dengan jalur laut menggunakan perahu tradisional. Kelurahan Molas, Kecamatan Bunaken, Kota Manado berbatasan dengan Kelurahan Bailang di bagian selatan dan bagian utara adalah Kelurahan Meras. Secara geografis stasiun I berada pada titik koordinat 1032'19,54" LU dan $124^{\circ} 49^{\prime} 25,46$ BT dan stasiun II berada pada titik koordinat 1032'17,78' LU dan 124ㄴ9'32,73 BT.

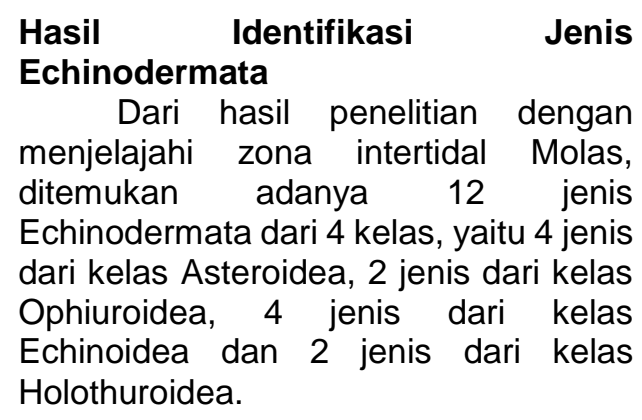




\section{Jenis-jenis Echinodermata}

a) Archaster typicus Müller dan Troschel, 1840

Bintang laut ini memiliki 5 buah lengan yang berukuran kisaran $7-10 \mathrm{~cm}$ dan mempunyai kaki tabung di sepanjang lengannya (Mappetahang, 2018). Menurut Fortaleza dkk. (2020), jenis bintang laut ini umumnya berwarna abu-abu muda dan biasanya menguburkan diri di pasir. Populasi $A$. typicus ditemukan di daerah pasang surut (intertidal) dengan substrat pasir karang.

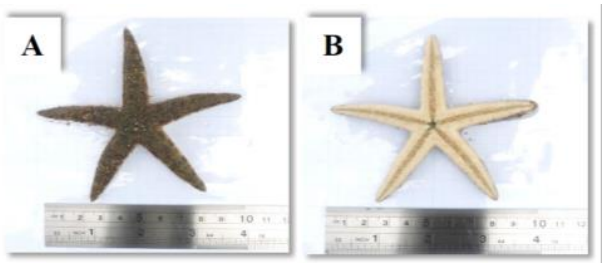

Gambar 2. Archaster typicus (a) Bagian aboral, (b) Bagian oral

b) Culcita novaeguineae Müller dan Troschel, 1842

Jenis bintang laut ini termasuk ke dalam famili Oreasteridae. Bintang laut ini tidak memiliki lengan dan sering disebut bintang laut bantal karena bentuk tubuhnya berbentuk seperti bantal. Tebal tubuh bintang laut ini berkisar dari $6-9 \mathrm{~cm}$ dengan diameter 16-23 cm (Fitriana, 2010).
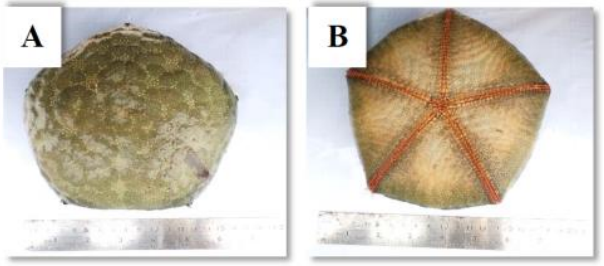

Gambar 3. Culcita novaeguineae

(a) Bagian aboral, (b) Bagian oral

c) Linckia laevigata Linnaeus, 1748

Menurut Fitriansyah dkk. (2018),

L. laevigata memiliki bentuk tubuh simetri radial dengan permukaan tubuh yang kasar, memiliki ukuran pusat tubuh berdiameter sekitar $3 \mathrm{~cm}$ dan panjang lengan sekitar $12,5 \mathrm{~cm}$. Clark dan Rowe (1971), menyatakan bahwa bintang laut ini memiliki lengan yang ramping dengan ujung yang tumpul.

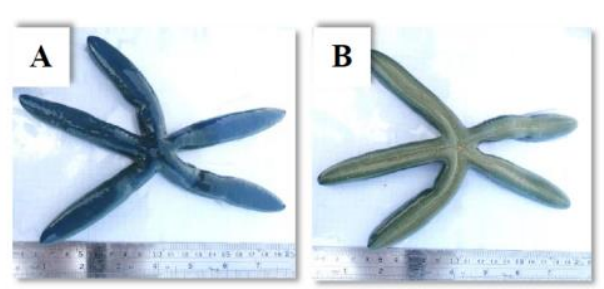

Gambar 4. Linckia laevigata (a) Bagian aboral, (b) Bagian oral

d) Protoreaster nodosus Linnaeus, 1758

Bintang laut ini memiliki warna tubuh yang bervariasi mulai dari merah tua, merah muda, cokelat pucat, hijau, biru hingga putih dan memiliki ukuran tubuh berkisar $12-17 \mathrm{~cm}$. Clark dan Rowe (1971), menyatakan bahwa bintang laut ini mempunyai karakteristik yaitu ukuran cakramnya yang sedang, dengan pelat kranial yang berbentuk seperti bantalan dan luas dengan bentuk yang pipih.

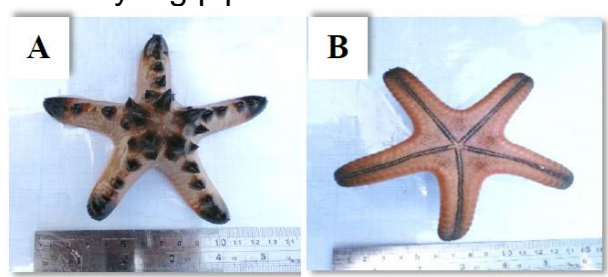

Gambar 5. Protoreaster nodosus (a) Bagian aboral, (b) Bagian oral

e) Ophiomastix annulosa Lamarck, 1816

Dari hasil pengamatan di lokasi penelitian, bintang ular laut kebanyakan ditemui di bawah bebatuan, hal ini sesuai dengan Fortaleza dkk. (2020) yang menjelaskan bahwa bintang ular laut biasanya bersembunyi di bawah bebatuan pada perairan dangkal.

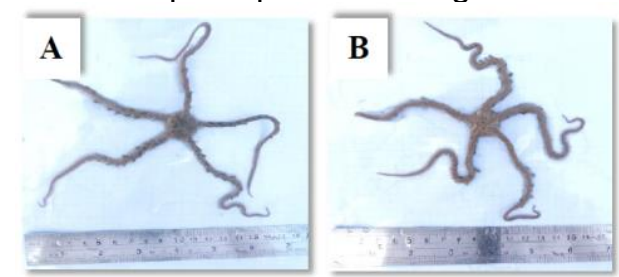

Gambar 6. Ophiomastix annulosa

(a) Bagian aboral, (b) Bagian oral

f) Ophiocoma scolopendrina Lamarck, 1816

Bintang ular laut ini memiliki warna tubuh coklat tua dan bervariasi di aboral tetapi sedikit lebih pucat di bagian oral (Clark dan Rowe, 1971). 
scolopendrina memiliki 5 lengan dengan panjang $\pm 8-15 \mathrm{~cm}$ (Triacha dkk., 2021). Pujayanti dkk. (2018) menyatakan bahwa 0 . scolopendrina biasanya ditemui pada daerah substrat yang keras dan dibawah celah-celah terumbu karang.

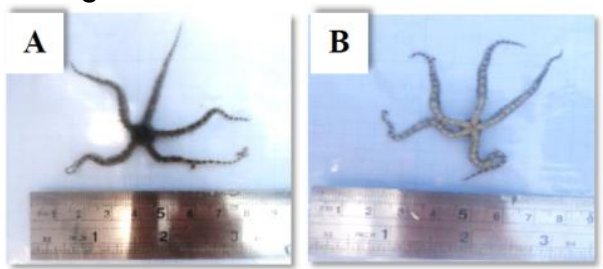

Gambar 7. Ophiocoma scolopendrina

(a) Bagian aboral, (b) Bagian oral

\section{g) Diadema setosum Leske, 1778}

Jenis $D$. setosum memiliki duri hitam yang panjang, hidup secara berkelompok dan banyak dijumpai pada substrat berpasir. Bulu babi ini memiliki bentuk tubuh yang bulat pipih dengan diameter tubuh sekitar 5,3-8,2 cm dan tinggi tubuh 3,6-5,6 cm (Sese, 2017).

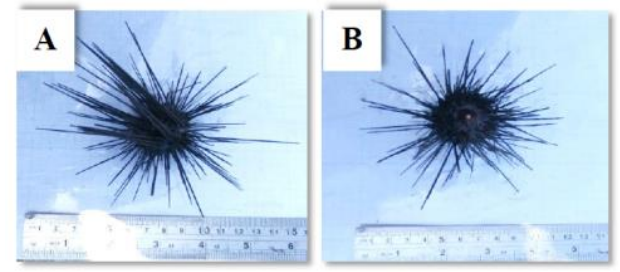

Gambar 8. Diadema setosum

(a) Bagian aboral, (b) Bagian oral

h) Echinothrix calamaris Pallas, 1774

Bulu babi ini memiliki duri ganda

yaitu duri primer berwarna belang sedangkan duri sekunder berwarna coklat halus dan runcing. Jenis ini memiliki diameter tubuh 6,2-7,2 cm dan tinggi tubuh 4,1-5,4 (Sese, 2017). Biasanya ditemukan pada daerah padang lamun.

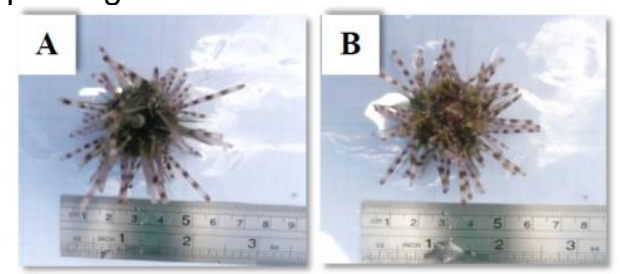

Gambar 9. Echinothrix calamaris

(a) Bagian aboral, (b) Bagian oral

i) Echinometra mathaei Blainville, 1825 Jenis Echinoidea ini memiliki bentuk tubuh bulat oval dan umumnya berwarna hijau, coklat, merah, merah muda, kuning dan putih. Memiliki diameter tubuh $3,2-4,4 \mathrm{~cm}$ dan tinggi tubuh 2,1-3,9 cm (Sese, 2017). Berdasarkan pengamatan dilapangan, jenis ini banyak ditemui pada substrat berbatu dan biasa menyembunyikan diri ke dalam sela-sela batu.
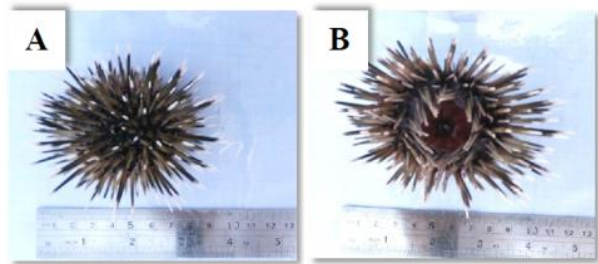

Gambar 10. Echinometra mathaei

(a) Bagian aboral, (b) Bagian oral

j) Tripneustes gratilla Linnaeus, 1758 Bulu babi ini memiliki bentuk tubuh bulat pipih dengan diameter tubuh sekitar 6,2-7,1 cm dan tinggi tubuh 4,3$5,4 \mathrm{~cm}$ (Sese, 2018). Dari hasil pengamatan dilapangan jenis bulu babi yang masuk dalam kelas Echinoidea ini ditemukan dalam jumlah yang sedikit dan hidup secara soliter.
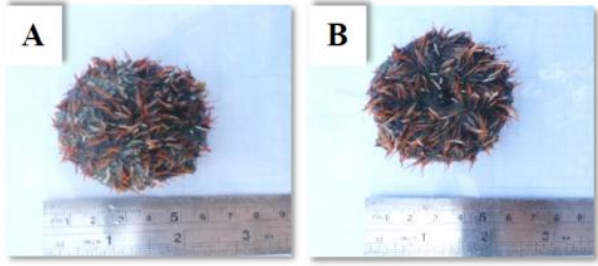

Gambar 11. Tripneustes gratilla

(a) Bagian aboral, (b) Bagian oral

k) Holothuria atra Jaeger, 1833

Rowe dan Doty (1977), menyatakan $H$. atra umumnya berwarna hitam dan hidup terbuka di area berpasir, tubuh teripang ini biasanya ditutupi dengan lapisan pasir. Tubuhnya memiliki panjang kurang lebih $20 \mathrm{~cm}$. Teripang ini dimanfaatkan sebagai makanan yang memiliki fungsi sebagai antibakteri yang bisa menyehatkan tubuh.

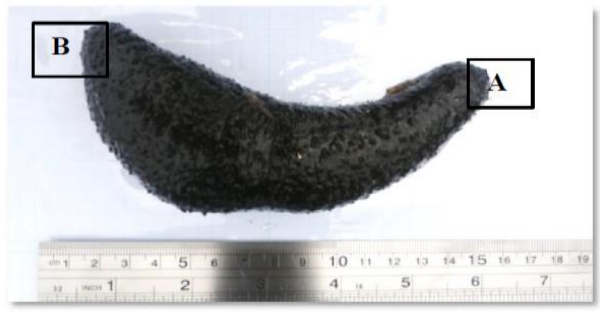

Gambar 12. Holothuria atra (a) Bagian Anterior, (b) Bagian Posterior. 
l)

Synapta maculata Chamisso \& Eysenhardt, 1821

James (2001), menyatakan jenis ini memiliki panjang tubuh seperti ular dan bisa mencapai panjang sekitar $2 \mathrm{~m}$. Dari hasil pengamatan di lapangan, tubuh teripang ini sangat elastis dam lengket apabila dipegang. Tubuh teripang ini umumnya berwarna belang keabu-abuan dengan pita atau bercak gelap melintang, jenis ini biasanya ditemui pada bawah batu atau diantara alga dan lamun (Rowe dan Doty 1977).

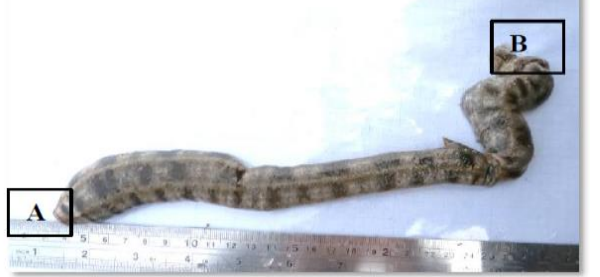

Gambar 13. Synapta maculata (a)

Bagian Anterior, (b) Bagian Posterior

\section{Indeks Keanekaragaman Jenis}

Berdasarkan hasil analisis indeks keanekaragaman jenis Echinodermata pada stasiun I diperoleh nilai $\mathrm{H}^{\prime}=1,666$ dan pada stasiun II diperoleh nilai $\quad H^{\prime}$ $=1,384$. Hasil ini menunjukkan bahwa keanekaragaman jenis pada kedua stasiun tergolong sedang. Hal tersebut selaras dengan kriteria Shannon-Wiener bahwa nilai $\quad H^{\prime} 1 \leq H^{\prime} \leq 3$. Perbedaan jenis dan jumlah individu mempengaruhi nilai keanekaragaman jenis dikarena adanya kecenderungan suatu jenis yang mendominansi populasi tersebut. Selain itu, keanekaragaman juga dilihat dari penyebaran individu dari setiap jenisnya (Simatupang dkk., 2017).

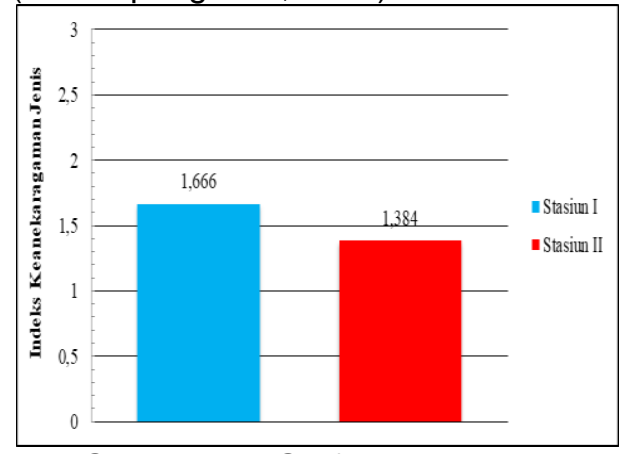

Gambar 14. Grafik Nilai Indeks Keanekaragaman Jenis

Bengkal dkk. (2019) menyatakan indeks keanekaragaman tergantung pada beragam jenis yang terdapat dalam suatu habitat, individu dan individu dari masing-masing jenis. Pada zona intertidal Molas, jenis Holothuroidea ditemukan dalam jumlah yang sedikit dikarenakan jenis dan populasi yang kurang dari perairan tersebut. Jenis Holothuroidea ditemukan dalam jumlah yang sedikit dikarenakan jenis ini memiliki selaput yang tipis, sehingga menyebabkan rendahnya adaptasi terhadap suhu lingkungan sekitarnya (Leksono, 2007). Keanekaragaman pada suatu perairan juga dapat menurun karena adanya tekanan secara ekologis. Tinggi rendahnya keanekaragaman juga disebabkan adanya tekanan ekologis berasal dari adanya aktifitas permukiman, transportasi maupun perikanan di sekitar lokasi (Katili, 2011).

\section{Indeks Kelimpahan Jenis dan Kelimpahan Relatif}

Hasil analisis indeks kelimpahan jenis menunjukkan pada stasiun I jenis $P$. nodosus memiliki kelimpahan tertinggi yaitu $1,133 \mathrm{ind} / \mathrm{m}^{2}$ 'dengan nilai kelimpahan relatif $40,48 \%$ dan jenis dengan nilai kelimpahan terendah L. laaevigata dan Holothuria atra dengan nilai $0,067 \mathrm{ind} / \mathrm{m}^{2}$ dan nilai kelimpahan relatif 2,38\%. Lokasi stasiun I sebagian besar memiliki tipe substrat berpasir dan ditumbuhi lamun yang diduga cocok untuk pertumbuhan bintang laut jenis $P$. nodosus. Jenis ini juga bisa hidup beradaptasi dengan lingkungannya dan umumnya hidup berkelompok (Mappetahang $d k k$, 2018). Penelitian sebelumnya oleh Ailen $d k k$. (2021) menunjukkan bahwa di perairan sekitarnya (Bahowo) dimana jenis $P$. nodosus paling banyak ditemukan di daerah padang lamun. Sedangkan pada stasiun II kelimpahan jenis tertinggi yaitu $D$. setosum dengan nilai $0,327 \mathrm{ind} / \mathrm{m}^{2}$ dengan nilai kelimpahan relatif $55,42 \%$ dan jenis dengan kelimpahan terendah $L$. laaevigata dan $C$. novaeguineae dengan nilai $0,067 \mathrm{ind} / \mathrm{m}^{2}$ dan nilai kelimpahan relatif $1,20 \%$. 


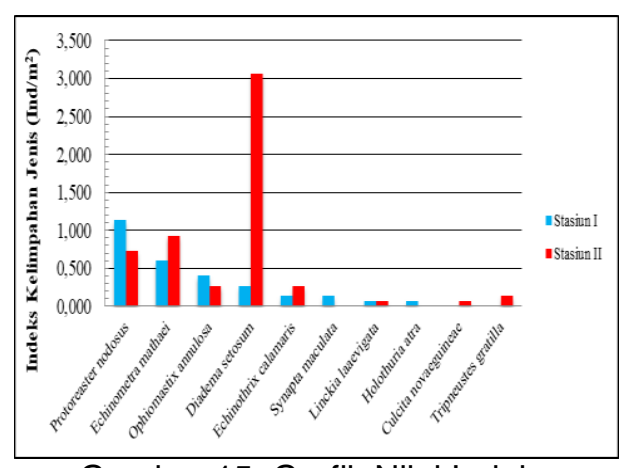

Gambar 15. Grafik Nilai Indeks Kelimpahan Jenis

Kelimpahan jenis Echinodermata pada suatu perairan dapat disebabkan oleh beberapa faktor seperti perbedaan jumlah jenis dan jumlah individu. Selain itu, komposisi substrat juga menentukan kelimpahan dan keberagaman jenis Echinodermata (Setyastuti dkk., 2018). Echinoidea jenis $D$. setosum memiliki kelimpahan jenis dan relatif tertinggi terutama di stasiun II menandakan bahwa jenis ini memiliki kemampuan daya adaptasi terhadap perubahan lingkungan. $\quad D$. setosum menyebar hampir pada semua habitat, yaitu merata pada zona rataan pasir, karang, lumpur maupun daerah tubir (Aziz 1996).

\section{Indeks Dominansi Jenis dan Dominansi Relatif}

Indeks dominansi digunakan untuk mengetahui jenis Echinodermata tertentu yang mendominasi suatu habitat. Berdasarkan hasil analisis indeks dominansi jenis pada kedua stasiun yaitu pada stasiun I sebesar $C$ $=0,245$ dan pada stasiun II sebesar $C=$ 0,359 . Nilai tersebut menunjukkan bahwa dominasi jenis pada kedua stasiun tergolong rendah, sesuai dengan kriteria Odum (1994) yang menyatakan bahwa apabila indeks dominasi jenis < 0,50 maka dominansi jenis tergolong rendah. Hal ini berarti belum terjadi persaingan yang berarti terhadap ruang, makanan, atau tempat hidup bagi organisme tersebut (Kambey $d k k ., 2015)$. Nilai indeks dominansi jenis pada stasiun II sedikit lebih tinggi dibandingkan stasiun I karena terdapat 1 jenis yang mendominansi yaitu jenis $D$. setosum dengan jumlah 42 individu.

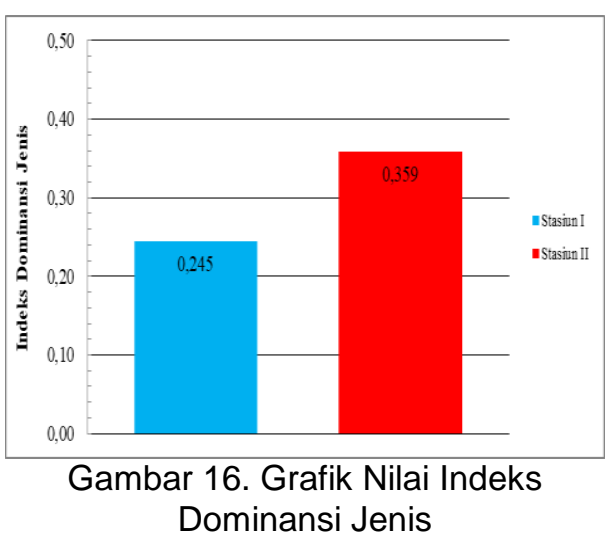

Hasil analisis indeks dominansi relatif menunjukkan bahwa pada stasiun I jenis $P$. nodosus memiliki nilai tertinggi sebesar $66,90 \%$ dan jenis dengan nilai terendah yaitu $L$. laevigata dan $H$. atra sebesar $0,23 \%$. Pada stasiun II jenis Diadema setosum memiliki nilai dominansi relatif tertinggi sebesar $85,63 \%$ dan jenis dengan nilai terendah yaitu $L$. laevigata dan novaeguineae sebesar $0.04 \%$. Setiap jenis memiliki pengaruh secara langsung seperti predasi dan secara tidak langsung seperti terjadinya perubahan habitat. Kedua hal tersebut memberi dampak terhadap penentuan jenis yang dominan (Levin, 2013).

\section{Indeks Frekuensi Jenis dan Frekuensi Relatif}

Frekuensi merupakan salah satu faktor penting untuk menentukan kehadiran dari masing-masing jenis pada tiap plot pengamatan. Berikut hasil analisis indeks frekuensi jenis (Gambar 17) yang disajikan dalam bentuk grafik.

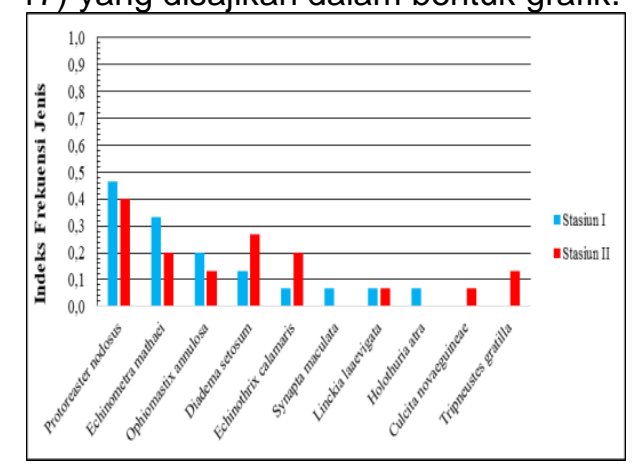

Gambar 17. Grafik Nilai Indeks Frekuensi Jenis

Berdasarkan grafik dapat dilihat bahwa, pada kedua stasiun jenis $P$. nodosus menunjukkan nilai frekuensi jenis tertinggi yaitu pada stasiun I 
sebesar 0,467 dan pada stasiun II sebesar 0,4. Hal ini diduga karena jumlah kehadiran jenis $P$. nodosus lebih banyak dibandingkan jenis lainnya. Sedangkan jenis dengan indeks frekuensi terendah yaitu $E$. calamris, $S$. maculata, L. laevigata, $H$. atra dan $C$. novaeguineae dengan nilai sebesar 0,067, jenis-jenis tersebut memiliki jumlah kehadiran paling sedikit pada kedua stasiun.

Nilai frekuensi relatif tertinggi pada stasiun I dan stasiun II yaitu jenis $P$. nodosus sebesar $33,33 \%$ dan $27,27 \%$ disusul jenis E. mathaeisebesar $23,81 \%$ dan jenis $D$. setosum sebesar $18,18 \%$. Sedangkan untuk frekuensi terendah yaitu jenis

C. novaeguieae sebesar 4,55\%. Hal ini karena pada kedua stasiun jenis ini ditemukan hanya sebanyak satu kali kehadiran. Jenis $P$. nodosus memiliki frekuensi yang tinggi. Hal ini disebabkan karena kedua stasiun memiliki tipe substrat yang cocok untuk jenis bintang laut ini. Daerah padang lamun merupakan sumber makanan bagi jenis tersebut yang berkaitan dengan kebiasaan anggota filum Echinodermata yaitu sebagai pemakan detritus dan pemakan suspensi di perairan (Lalombombuida dkk., 2019).

\section{Indeks Nilai Penting}

Indeks nilai penting dilakukan untuk melihat peran suatu jenis terhadap suatu kawasan (Kurniawan dkk., 2017). Berdasarkan hasil penjumlahan nilai kelimpahan relatif, dominansi relatif dan frekuensi relatif maka indeks nilai penting (INP) masingmasing jenis, pada stasiun I jenis $P$. nodosus memiliki nilai tertinggi sebesar 140,71 sedangkan nilai terendah jenis $L$. laaevigata dan $\quad H$. atra sebesar 7,37. Pada stasiun II jenis $D$. setosum memiliki nilai tertinggi sebesar 159,23 sedangkan nilai terendah jenis $L$. laaevigata dan

C. novaeguineae sebesar 5,79.

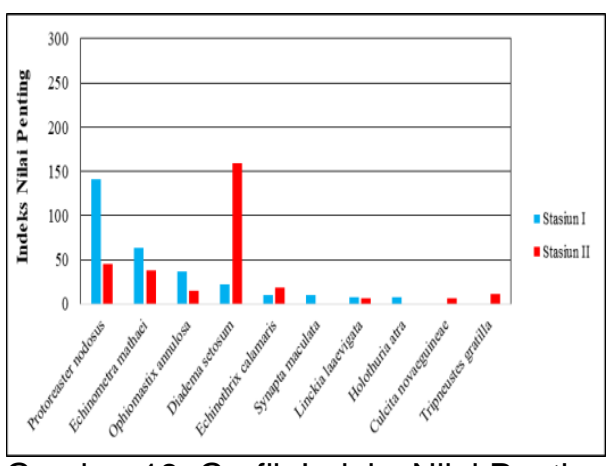

Gambar 18. Grafik Indeks Nilai Penting

Analisis indeks nilai penting digunakan untuk menduga peran suatu jenis terhadap suatu komunitas, maka dengan nilai yang diperoleh jenis $D$. setosum menunjukkan nilai tertinggi, diikuti jenis $P$. nodosus. Hal ini berarti bahwa jenis $D$. setosum yang paling mendominasi serta memiliki peranan penting dalam komunitasnya. Kehadiran populasi $D$. setosum sangat penting dalam mencegah pertumbuhan alga yang berlebih. Hal ini sejalan dengan pendapat Suryanti dan A'in (2013) bahwa kesetimbangan populasi $D$. setosum akan menjaga kesetimbangan populasi alga dan karang.

Hasil Parameter Fisika Kimia Perairan Berdasarkan hasil pengukuran parameter fisika-kimia perairan yang telah dilakukan pada lokasi penelitian yang meliputi, suhu, $\mathrm{pH}$ dan salinitas perairan, diperoleh data kondisi fisikakimia perairan yang menunjukkan variasi nilai tidak berbeda jauh pada setiap stasiun pengamatan. Pada pengamatan hari kedua suhu perairan cukup tinggi dikarenakan keadaan cuaca pada saat pengukuran yang terlalu panas.

Tabel 1. Hasil pengukuran parameter fisika-kimia perairan

\begin{tabular}{|c|c|c|}
\hline No. & Parameter & Hasil \\
\hline 1 & Suhu $\left({ }^{\circ} \mathrm{C}\right)$ & $29-32$ \\
\hline 2 & $\mathrm{pH}$ & $7-8$ \\
\hline 3 & Salinitas (\%o) & $29-30$ \\
\hline
\end{tabular}

Suhu perairan Molas berkisar 29$32^{\circ} \mathrm{C}$. Hal tersebut menunjukkan bahwa suhu pada perairan tersebut dalam 
keadaan normal sehingga baik untuk kehidupan Echinodermata. Sedangkan hasil pengukuran $\mathrm{pH}$ pada lokasi penelitian yakni 7-8. Nilai salinitas perairan Molas yakni 29-30\%o (ppt). Pengukuran parameter dilakukan secara in situ tanpa adanya pengulangan musim dimana pengukuran dilakukan sesaat sehingga variasi parameter perairan akan berbeda di musim yang lain.

Hasil pengukuran parameter lingkungan di perairan Molas Kecamatan Bunaken, Kota Manado, menunjukkan bahwa parameter lingkungan perairan tersebut tergolong normal. Hal ini karena lokasi perairan jauh dari aktivitas manusia dan tidak adanya muara sungai di sekitar lokasi penelitian yang bisa membawa masuk bahan pencemar di perairan.

\section{Tipe Substrat}

Secara keseluruhan, zona intertidal Molas memiliki beberapa tipe substrat dasar antara lain pasir, lumpur, berbatu maupun pecahan karang yang dijadikan habitat bagi beberapa organisme seperti Echinodermata. Pada metode jelajah substrat dasar pada stasiun I cukup bervariasi yaitu sebagian besar substrat berpasir serta pecahan karang dan sedikit berlumpur. Sedangkan substrat pada stasiun II terdiri dari substrat berpasir dan berbatu. Radjab dkk. (2014), menyatakan bahwa substrat berpasir, pasir berlumpur bercampur dengan pecahan-pecahan karang serta banyak terdapat tanaman air seperti rumput laut atau lamun mengandung detritus sebagai makanan echinodermata sehingga echinodermata dapat hidup dengan baik di substrat tersebut.

Berdasarkan pengamatan menggunakan metode transek kuadrat, substrat dasar pada stasiun I memiliki satu tipe substrat dasar yaitu berpasir. Sedangkan pada stasiun II terdiri dari substrat berpasir dan berbatu. Dari hasil pengamatan pada keseluruhan stasiun didapatkan bahwa tipe substrat berpasir lebih mendominansi. Substrat perairan berperan penting bagi kehidupan organisme bentik yaitu untuk dijadikan tempat tinggal, mencari makan dan melindungi diri dengan cara membenamkan diri ke dalam substrat tersebut (Wahyuni, 2018).

\section{KESIMPULAN}

1. Pada zona intertidal Molas telah ditemukan Filum Echinodermata yang diperoleh secara keselurahan meliputi empat kelas yaitu kelas Asteroidea, Echinoidea, Ophiuroidea, dan Holothuroidea dengan total 12 jenis. Jenis-jenis tersebut yaitu $A$. typicus, novaeguineae, L. laevigata,

C. nodosus, $D$. setosum,

$P$. calamaris, E. mathaei, T. gratilla, $O$. annulosa, O. scolopendrina, $H$. atra dan S. maculata.

2. Berdasarkan hasil penelitian diperoleh indeks keanekaragaman jenis $\left(H^{\prime}\right)$ pada kedua stasiun tergolong sedang. Sedangkan indeks dominansi jenis (C) tergolong rendah. Berdasarkan hasil analisis beberapa indeks ekologi maka diperoleh bahwa jenis Diadema setosum memiliki nilai tertinggi.

\section{DAFTAR PUSTAKA}

Ariyanto, T. P. 2016. Keanekaragaman dan kelimpahan Echinodermata di Pulau Barrang Lompo Kecamatan Ujung Tanah Kota Makassar. Skripsi. Jurusan Biologi, Fakultas Sains dan Teknologi UIN Alauddin, Makassar. 71 hal.

Aziz, A. 1996. Habitat dan zonasi fauna ekhinodermata di ekosistem terumbu karang. Oseana, 21(2), 33-43.

Bengkal, K.P., I.S. Manembu., C.F.A. Sondak., B.T. Wagey., J.N.W. Schaduw dan L.J.L. Lumingas. $2019 . \quad$ Identifikasi keanekaragaman lamun dan ekhinodermata dalam upaya konservasi. Jurnal Pesisir dan Laut Tropis, 1(1), 29-39.

Budiman, C.C., P.V. Maabuat., M.L.D. Langoy dan D.Y. Katili. 2014. Keanekaragaman Echinodermata di Pantai Basaan Satu Kecamatan Ratatotok Sulawesi 
Utara. Jurnal MIPAUNSRAT Online, 3(2), 97-101.

Colin, P dan C. Arneson. 1995. Tropical Pasific Invertebrates: A Field Guide To The Marine Invertebrates Occuring On Tropical Pasific Coral Reefs, Seagrass Beds And Mangroves. Coral Reef Press. 296 hal.

Dahuri, R. 2003. Keanekaragaman Hayati Laut: Aset pembangunan berkelanjutan Indonesia. Jakarta: Gramedia Pustaka Utama. 412 hal.

Eman, A.I., E.Y. Kaligis., C.A. Sinjal dan B.T. Wagey. 2021. Keanekaragaman dan kepadatan Echinoidea dan Asteroidea di Rataan Terumbu Karang Perairan Tongkaina dan Bahowo Kota Manado. Jurnal Pesisir dan Laut Tropis, 9(1), 11-21.

Fitriana. N. 2010. Inventarisasi bintang laut (Echinodermata: Asteroidea) di Pantai Pulau Pari, Kabupaten ADM. Kepulauan Seribu. Jurnal Ilmiah Faktor Exacta, 3(2), 167174.

Fitriansyah, M.Y.F. Arifin dan D. Biyatmoko. 2018, Identifikasi Echinodermata di persisir Pulau Denawan, Kecamatan Pulau Sembilan. Prosiding Seminar Nasional Lingkungan Lahan Basah, 3(1), 157-163.

Fortaleza M.A., J.J. Lanutan., J.M. Consuegra dan C.L Nañola. 2020. Diversity of echinoderms in intertidal and shallow-water areas of Samal Island, Philippines. Philippine Journal of Science, 150 (S1), 281-297.

James, D.B. 2001. Twenty sea cucumbers from seas around India. Naga, The ICLARM Quarterly, 24 (1 dan 2), 4-8.

Kambey, A.G., U.N.W.J. Rembet dan A.S. Wantasen. 2015. Komunitas Echinodermata di daerah intertidal perairan Pantai Mokupa Kecamatan Tombariri Kabupatem
Minahasa. Jurnal IImiah Platax, 3(1), 10-15.

Katili, A.S. 2011. Struktur komunitas Echinodermata pada zona intertidal di Gorontalo. Jurnal Penelitian Pendidikan, 8(1), 5161.

Kurniawan, M.R., S. Nasution dan Yoswati, D. 2017. Struktur komunitas Echinodermata di Taman Wisata Perairan Pulau Pieh Provinsi Sumatera Barat. Jurusan IImu Kelautan, Fakultas Perikanan dan Kelautan, Universitas Riau, Pekanbaru, Provinsi Riau. 2-18.

Lalombombuida, S., M. Langoy dan D.Y. Katili. 2019. Keanekaragaman Echinodermata di Pantai Paranti Desa Tabang, Kecamatan Rainis Kabupaten Kepulauan Talaud Provinsi Sulawesi. Jurnal Perikanan dan Kelautan Tropis, 10(2), 39-50.

Leksono, A.S. 2007. Ekologi pendekatan deskriptif dan kuantitatif. Malang: Bayu Media Publishing. 210 hal.

Levin, S.A. 2013. Encyclopedia of biodiversity: Second Edition. Elsevier Inc, Princeton University, Princeton, New Jersey, USA. 5504 hal.

Odum, E.P. 1994. Dasar-Dasar Ekologi, Penerjemah: Samingan, T Dan B, Srigandono. Gajahmada University Press. Yogyakarta. Terjemahan Dari Fundamental of Ecology. 677 hal.

Pujayanti, N.K.A.N., I. Bachtiar dan Khairuddin. 2018. Kelimpahan dan struktur populasi Ophiocoma scolopendrina (Ophiuroidea) di Kawasan intertidal Pantai Pewaringan Kabupaten Lombok Utara. Program Studi Pendidikan Biologi, Jurusan Pendidikan MIPA, FKIP, Universitas Mataram. 1-9.

Radjab, A.W., S.A. Rumahenga., A. Soamole., D. Polnaya dan W. 
Bareds. 2014. Keragaman dan kepadatan ekinodermata di Perairan Teluk Weda, Maluku Utara. Jurnal IImu dan Teknologi Kelautan Tropis, 6(1), 17-30.

Rompis, B.R., M.L.D Langoy., D.Y. Katili dan A. Papu. 2013. Diversitas Echinodermata di Pantai Meras Kecamatan Bunaken Sulawesi Utara. Jurnal Bioslogos, 3 (2), 26 30.

Rowe, F.W.E. 1969. A Review of family Holothuroidae (Holothuroidae: Aspidochiroti-da). Bulletin of British Museum Natural History Zoology, 5(6), 117-170.

Rowe, F.W.E. dan J.E. Doty 1977. The shallow-water Holothurian of Guam. Micronesica, 13(2), 217 250.

Sara A., L.T.X. Lalamentik dan A.B. Rondonuwu. 2020. Struktur komunitas lamun (seagrass) di perairan pantai Kelurahan Molas, Kecamatan Bunaken Kota Manado Sulawesi Utara. Jurnal IImiah Platax, 7(1), 44-52.

Sese, M.R., Annawaty, dan E. Yusron. 2018. Keanekaragaman Echinodermata (Echinoidea dan Holothuroidea) di Pulau Bakalan, Banggai Kepulauan, Sulawesi Tengah, Indonesia. Scripta Biologica, 5(2), 73-77.

Simatupang, M.Y.C., M.A. Sarung dan M. Ulfah. 2007. Keanekaragaman

Echinodermata dan kondisi lingkungan perairan dangkal pulau Pandang Kabupaten Batu Bara Provinsi Sumatera Utara. Jurnal Ilmiah Mahasiswa Kelautan dan Perikanan Unsyiah, 2(1), 97-103.

Supono., D.J.W. Lane dan Susetiono. 2014. Echinoderm fauna of the Lembeh strait, North Sulawesi: inventory and distibution review. Mar Res Indonesia. 39(2), 51-61.

Tahe, O.S., M.L.D. Langoy, D.Y., Katili dan A. Papu. 2013.
Keanekaragaman Echinodermata di Pantai Tanamon Kecamatan Sinonsayang Sulawesi Utara. Jurnal Bios Logos, 3(2), 65-72.

Triacha, Z.I.E.C., M.P. Pertiwi dan R.T. Rostikawati. Keanekaragaman Echinodermata di Pantai Cibuaya Ujung Genteng, Jawa Barat. Jurnal IImu Dasar, 22(1), 9-18.

Wahyuni, S. 2018. Studi tentang struktur komunitas Echinodermata pada ekosistem lamun Pantai Pandaratan Kabupaten Tapanuli Tengah Provinsi Sumatera Utara. Skripsi. Program Studi Manajemen Sumberdaya Perairan Fakultas Pertanian Universitas Sumatera Utara. 73 hal.

Yusron, E. 2010. Keanekaragaman jenis ekhinodermata di perairan Likupang, Minahasa Utara, Sulawesi Utara. IImu Kelautan, 15(2), 85-90.

Zamani, N.P. 2015. Kondisi terumbu karang dan asosiasinya dengan bintang laut (Linckia laevigata) di Perairan Pulau Tunda, Kabupaten Seram, Provinsi Banten. Jurnal Teknologi Perikanan Kelautan, 6(1), 1-10. 